Papers and Proceedings of the Royal Society of Tasmania, Volume 116, 1982

(ms. received 5.10 .1981$)$

\title{
FIRES BY THE SEASIDE: HISTORIC VEGETATION CHANGES IN NORTHWESTERN TASMANIA
}

\author{
by Jim Stockton \\ Department of Prehistory, A.N.U., Canberra, A.C.T.
}

(with two tables and three text-figures)

ABSTRAC'T

STOCKTON, J., 1982 (31 viii): Fires by the seaside: historicvegetation changes in north-

western Tasmania. Pap. Proc. R. Soc. Tasm., 116: 53-66.

https://doi.org/10.26749/rstpp.116.53 ISSN0080-4703. Department of Prehistory, Australian National

University, Canberra, A.C.T.

Dramatic changes in landscape and vegetation have occurred on the northern section of the west coast of Tasmania since the invasion by Europeans. Insidious changes such as the introduction of new species are to be expected but the destabilization of large sections of a major landform has also occurred with the development of extensive sand blows. A variety of forms of evidence relating to changes in land use patterns are examined in an attempt to date the start, and assess the extent, of this change.

\section{INTRODUCTION}

While searching explorers' diaries and reports for information about the prehistoric inhabitants of northwestern Tasmania I encountered descriptions of vegetation patterns that were often quite different from those observed today. This paper grew as an attempt to synthesize the early vegetation descriptions for the coastal strip of the region. Arbitrary geographical limits are set at the entrance to Macquarie Harbour in the south

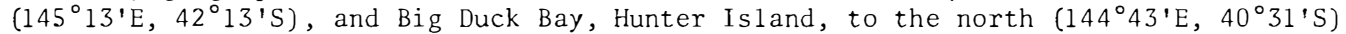
(see figure 1). The coastal strip discussed is approximately $1 \mathrm{~km}$ wide.

\section{BACKGROUND}

The west coast of Tasmania is often regarded as a wild landscape; to many visitors it does not appear to have changed greatly since Aboriginal times. Yet as unfriendly as this region seems to our culture, it was the home territory for groups of prehistoric hunters who left evidence of their activities on almost every part of the landscape. The area has seen intense archaeological and ethnographic research in the last 20 years. I propose to look at only two aspects in detail, landforms and vegetation patterns. Historic descriptions of vegetation and landforms along the coast at the period of European contact will be compared to the patterns of vegetation and landforms of the region today.

There are a number of problems in attempting this, some familiar to historians, but others more familiar to botanists, ecologists, and geographers.

Many of the place names in early accounts are no longer used, while other names have moved in the landscape (Stockton 1979; Mackanness 1976, 39) so relocation of what an observer was describing can be extremely difficult. This relocation can sometimes be achieved by map reading, air photo interpretation or by visiting the locality, but some descriptions could not be used as the localities of the given place names are no longer known.

Some travellers gave only the vaguest hints of the route they followed and some even had their major landmarks like mountains and large rivers confused (e.g. see Plomley 1966 , 903). Others, particularly surveyors, drew maps to accompany their reports and diaries. Although these can be extremely inaccurate, some maps give boundaries of their 


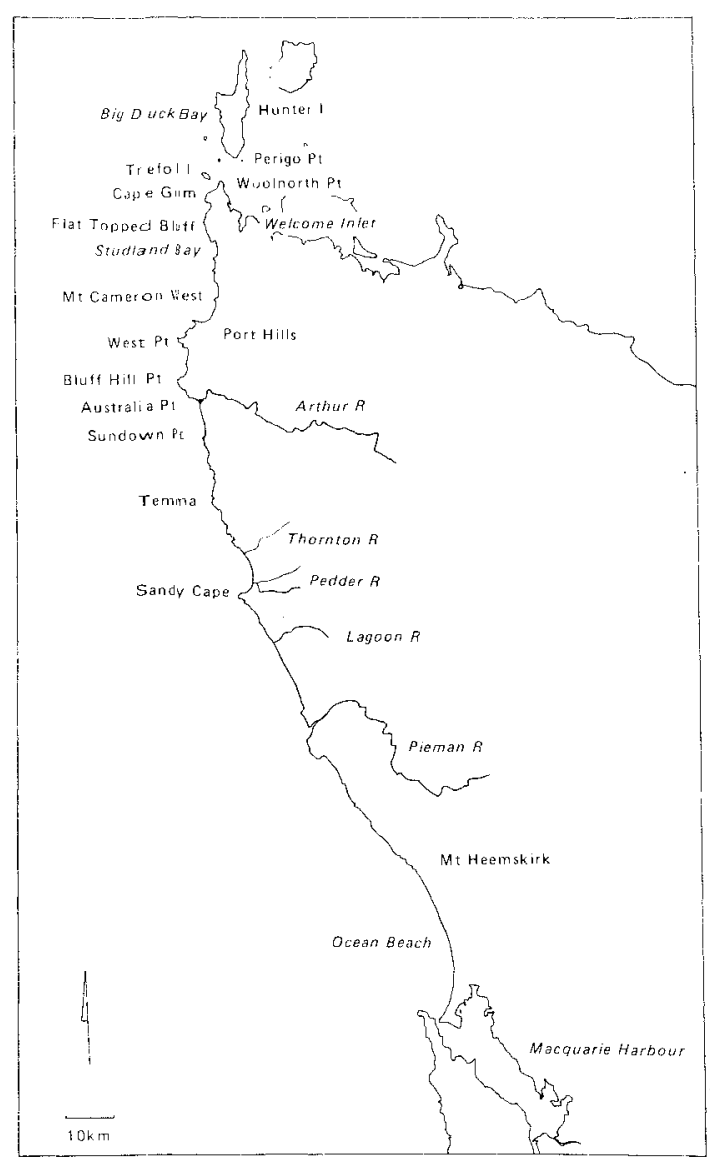

FIG.I - Map of study area and place names used in text. observations of vegetation (see figure 2). Appendix 1 sets out the total of 43 observations which can be accurately relocated.

Common plant names have remained stable in the area over the past 150 years and most of the terms of 1820 are still in use today. Scientific names have been a little more fluid as taxonomic studies have progressed.

The final problem is that few of the early explorers were trained observers competent to describe plants, plant communities, soils, landforms and geology. All were recent immigrants to the colony to whom Tasmania was bizarre and alien. Hardwicke (1861) was a ship's captain who carried out a reconnaissance from the sea about 1824. C.P. Lorymer (1861), Joseph Fossey (1861), Alexander Goldie (1861) and Henry Hellyer (1861) were surveyors and agriculturalists working for the Van Diemen's Land Company, a large agricultural firm granted 1 and in northwestern Tasmania, but managed from England. These reports cover surveys carried out in the $1820^{\prime} \mathrm{s}$. Original maps from these surveys have survived, which together with their reports provide excellent geographical records. John Helder Wedge (1861, 1962) was a government surveyor sent to inspect the land available for selection by the Van Diemen's Land Company. George Augustus Robinson, by trade a builder, was appointed Conciliator to the Tasmanian Aborigines. All these men showed courage and endurance in travelling through the unknown landscape of Tasmania of the early $1800^{\prime} \mathrm{s}$. That they managed to record their field observations so well was a feat of intellectual endurance.

\section{VEGETATION COMMUNITIES AND LANDFORMS}

The early explorers used four broad categories to describe the vegetation patterns they encountered: heath, tea-tree swamp, forest and grassland. In the following sections the patterns of relationships between vegetation communities and landforms will be examined. Evidence for changes in these patterns will be presented for each community.

Heath communities

In the historical record large areas of heath are described. Banksia marginata is the most commonly noted species. The descriptions probably include sedgeland heath in this comminity, though it is rarely explicitly stated. There are few references to $5 c r u b$ communities. Either the explorers did not encounter dense scrub on the coast, or they failed to record it. Heath species would develop a scrub structure if the shrubs are 
allowed to grow more than two metres tall. On the coast plant height is regulated by nutrition, waterlogging, buffeting by wind, salt spray and fire frequency. Nutrition, waterlogging, wind and salt spray factors can be taken as constant over time, so the variable to examine is fire frequency.

In the Lands Department cattle agistment runs extending from West Point to the Pieman River the preferred fire frequency interval is about $3-5$ years ( $J$. Hanson pers. comm.). This ideal is only obtained in areas of easy access such as along roads and tracks. Extensive areas of less accessible heath community have moved towards a closed scrub. References to Aboriginal burning are abundant and $I$ shall return to this point later.

Tea-tree swamp communities

Sheltered waterlogged locations are described by the explorers as supporting tea-tree communities. These are easily recognizable as the Melazeuca spp. and Leptospermum spp. dominated communities which develop into a very dense forest of low trees in sheltered swamp localities. The blackwood, Acacia melanoxyzon, which is cut for milling, grows in the larger swamps. East of the coastal strip, some large areas of teatree swamp have been altered by draining and clearing for farmland, e.g. Togari, but the swamps near the coast are not large enough to warrant this sort of activity.

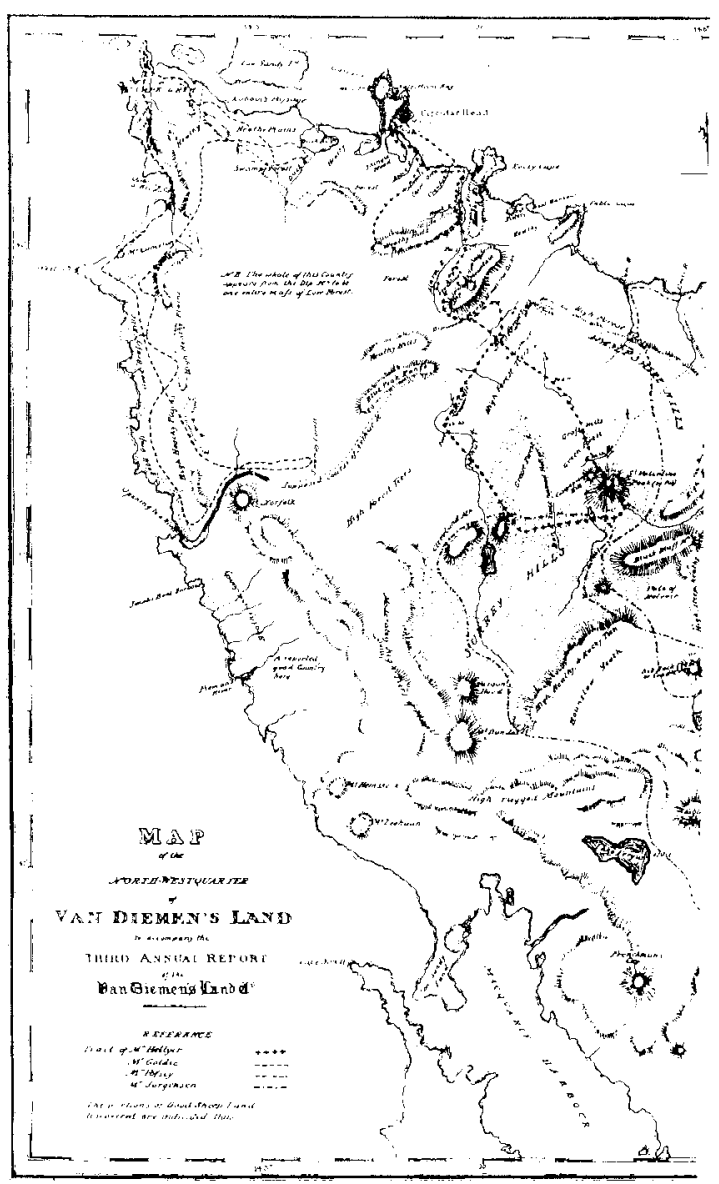

FIG. 2 - Map to accompany the Third Annual Report of the Van Diemen's Land Company (VDL/343/5).

\section{Forest communities}

There were no rainforests along the coastal strip, although large areas inland were dominated by a Nothofagus

cunninghamii community. Patches of eucalypt forest did occur on areas of better soil such as the basalt soils of Mount Cameron West and the Port Hills. The vegetation structure appears to have been tending towards an open woodland.

Today the Port Hills are largely cleared for pasture, but stumps of large Eucalyptus trees remain. The southern and eastern lower slopes of Mount Cameron West are now an open woodland of E'. viminalis-E. ovata over a Poa grassland and Lomandra Zongifolia tussock understorey (Brown 1980, 26). This area probably looks much as it did when the first settlers arrived, but other parts of the mountain are under pasture.

\section{Grassland communities}

The early explorers were looking for areas suitable for English sheep and cattle, so perhaps these communities were "over recorded" in their diaries and reports while too little mention was made of less economically valuable communities. Fortunately, maps of areas suitable for sheep were made by Van Diemen's Land Company surveyors and the diaries 


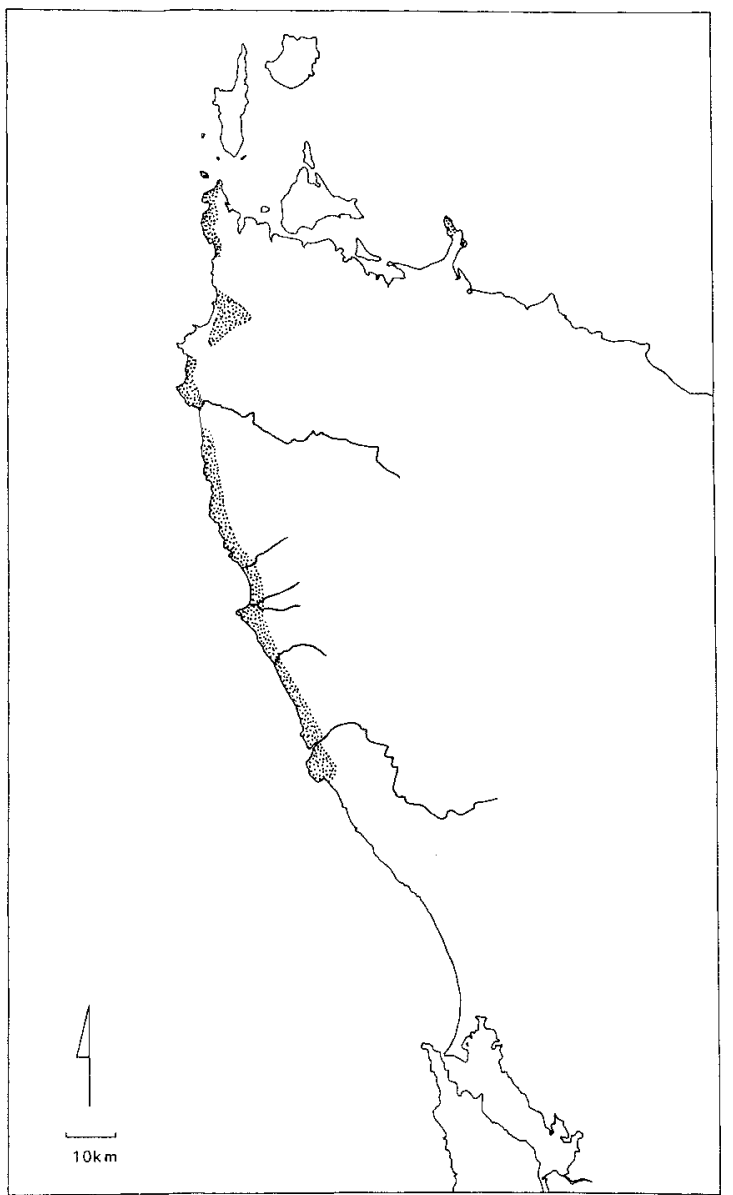

FIG. 3 - Figure 2 redrawn on a modern base map. and reports can be cross-checked against these. The level of agreement is surprisingly high. Figure 2 is an example of one of these maps.

Figure 3 is an attempt to redraw this on a modern base map. The scenario conveyed by the early accounts is of large tracts of grassland with scattered trees and shrubs on southwestern Hunter Island, Woolnorth Point to Studland Bay, Mount Cameron West, and a discontinuous coastal strip from Mount Cameron west to about $10 \mathrm{~km}$ south of the Pieman River. The descriptions repeatedly mention grassy hills, parklike appearances and suitability as sheep runs. The scattered trees noted in this community are Banksia marginata, Melazeuca spp., and dwarf gum - probably mallee form E. nitida. The only grass species named is "kangaroo grass" (Goldie 1861, 6; Plomley 1966, 619). J.D. Hooker in the Flora of Tasmania described Anthistiria australis $\mathrm{R}$. Br. as having the

"Colonial name - Kangaroo Grass" $(1860,107)$. The name has since been changed to Themeda australis and it is still called "kangaroo grass"

(M. Cameron pers. comm.). However M. Brown (pers. comm.) suggests the habitats Robinson described do not sound right for Themeda but seem more appropriate for Poa poiformis or possibly Poa LabizLardiexi. Themeda occurs on calcarenite ridges and swales but avoids siliceous sands or recent dunes. The Poa spp. are rarely found more than $500 \mathrm{~m}$ from the sea (G. Hope pers. comm.)

The attempts to run sheep on these grasslands were short lived, lasting less than five years. Soil deficiencies, particularly of cobalt and copper (Colin Bastock pers. comm.) produced a condition called "coastiness" and many animals died. By 1834 the sheep had been removed from West Point and Studland Bay (Plomley 1966, 844). Later cattle, which are more resistant to these deficiencies were tried, usually on a short-term basis such as while being driven to market at the mining towns further south. Today most of the region is used only for winter agistment of cattle, a form of regulated free range grazing.

These prehistoric grasslands grew on two soil types - basaltic soils at Cape Grim and the Port Hills and sandy soils on Quaternary sandsheets on Hunter Island, at Studland Bay, north of Mount Cameron West, and on the discontinuous strip south of the mountain to the Pieman River. The basaltic soil areas have mostly been cultivated and sown to pasture (see Appendix 1, references 4, 7, 8, 9, 10,15, 18, 19, 21, 23). The sandsheet grasslands have changed in other ways. 


\section{Jim Stockton}

The sandsheets on which the grassland community grew have been drastically altered in most areas. Deflation of the sand dunes by wind is one of the outstanding features of the west coast today. The development of the sand blows is poorly documented and I have not yet been able to determine when the process started, only that sand blows are not mentioned by any of the explorers. Legge (1929, 323-324) cited second-hand descriptions of the process starting after 1880 .

"Pioneer settlers of this coast, such as those of Marrawah, for instance, can remember, when, some 45 years ago, they first took up 1 and out there, these great sand-dunes being covered with dense coastal scrub right down close to the edge of the wild beaches, but since the introduction of stock, and on account of the periodical burnings by the graziers for improvement of the rough pastures, the surface of the light soil has been broken, and tracks and pathways have been made, allowing the wind to make inroads upon the sandy soil, laying bare the roots of plants and trees, carrying on its work of denudation, leaving today many areas of absolute desert land."

The process is continuing today in spite of some 50 years of marram grass planting programs in the area (D. Steane pers. comm.).

of the areas formerly described as grassland communities on stable sand dune landforms less than $60 \%$ remain. It was difficult to estimate the area of these landscape units without lengthy calculations. Fortunately, the coastal mapping operation of the CSIRO Division of Land Use Research, provided a way of estimating the total Holocene sand area, and the area of bare Holocene sand (Galloway et al. 1980). The system of measurement used by the CSIRO is based on point samples spaced so as to give one sample per $3 \mathrm{~km}^{2}$ (Galloway et al. 1980, 7). The results of this method of sampling for the coastal strip from Woolnorth Point to Macquarie Harbour gives estimates of $165 \mathrm{~km}^{2}$ of Holocene sand of which $66 \mathrm{~km}^{2}$ or $40 \%$ is bare of vegetation. As restabilized areas of marram grass are not included in the bare sand unit, the area of Holocene sand which has been unstable in the recent past is even greater. The largest grassland remnants are at Temma, Australia Point, Arthur River mouth, and southwestern Hunter Island. Of these, Hunter Island conforms most closely to a structure commonly described in 1820-1840, i.e. of a grassland with scattered emergent low trees of Banksia marginata and Eucazyptus spp. - almost a "savannah" pattern.

Relict dune landforms with grassland seem to have survived where the foreshore contains extensive rock platforms, e.g. Greens Creek, north of Temma, north of Lagoon River or where the beach line is aggrading, e.g. the southern half of Ocean Beach. These situations lessen the probabiljty of the front dune being undercut by wind or wave removal of sand. Kirkpatrick $(1977 \mathrm{~b}, 70)$ described small areas of natural grassland on a narrow coastal strip, and in a few swales in the Holocene sand dune complex at Ocean Beach. The coastal strip north of Trial Harbour is dominated by Poa poiformis tussock grass.

In the summers of $1979 / 80$ and $1980 / 81$ samples of the most common grasses of the remnant grassland community in the vicinity of West Point were collected. About half the species of this area of marginal land with minimal management proved to be exotic (table 1). Management today consists solely of firing the vegetation to produce new growth, or "green pick" in local vernacular. In the past there may have been more intense management. There is a folk tradition that farmers would travel along the coast on horseback and flick lighted matches into the vegetation to start fires. On the return journey they would carry a bag of mixed grass seeds on the front of the saddle and scatter seed over the burnt ground. One of the grasses in the mixture was likely to find conditions suitable for growth. Introduced grass species would also be carried into the area in the gut contents of horses and cattle. Many of the species in the list are no longer regarded as pasture grasses, but were introduced for that purpose. Some have very short growing seasons, and could not compete in modern pastures. The presence of clovers adds an interesting complication. These nitrogen-fixing legumes increase soil fertility, thus facilitating invasion of new species not adapted to the very poor native soils. 
TABLE 1

MOST COMMON SPECIES GOR REMNANT GRASSLAND AREA AT WEST POINT.

\author{
Indigenous Exotic
}

Agrostis stolonifera Asperula conferta

Bromus diancirus

Cakize edentula

Dactyzis glomerata

Danthonia sp.A

Danthonia sp.B

Dichondra repens

Epizobium hirtigemam

Holcus zanatus

Juncus articulatus

Lepidosperma gladiatum

Lotus australis

\begin{tabular}{|c|c|c|}
\hline \multirow{3}{*}{$x$} & $\mathrm{x}$ & Lythrum hyssopifotium \\
\hline & & Medicago Zubulina \\
\hline & $x$ & Melizotus indica \\
\hline$x$ & & Parentuceltia viscosa \\
\hline & $\mathrm{x}$ & Plantago coronobus \\
\hline & $x$ & Plantago Zanceolata \\
\hline & $x$ & Poa pratensis \\
\hline$x$ & & Poa rodwayi \\
\hline$x$ & & Scirpus nodosus \\
\hline & $\mathrm{x}$ & Senecio hispidulus \\
\hline$x$ & & Stipa stipoides \\
\hline$x$ & & Tetragonia implexicoma \\
\hline$x$ & & Trifolium repens \\
\hline
\end{tabular}

Indigenous Exotic

\section{IMPACT OF VEGETATION CHANGE ON STABILITY OF SANDSHEET LANDFORMS}

In describing the coastal landforms of Tasmania Davies noted two forms of dunes. One of these is a "transgressive dune originating from wind erosion of a pre-existing stabilized dune" (1965, 22). Davies suggested that there is evidence from many coastal areas that the present cycle of transgressive dune development began in the nineteenth century as a result of burning and stocking of dune country previously stabilized by vegetation.

The mechanics of the formation of unconsolidated dunes were described by Macphail et al. (1975, 59).

"This process starts usually with fire damage to the vegetation on the front of the foredune, or from damage by vehicles or cattle to the base of the dunes.

Removal of sand undercuts the vegetation higher up the dune, with consequent

slumping and removal of the unconsolidated sand by wind funneling. Sand moved

from the dune front is deposited on the lee of the front dune, burying the heath

and scrub. Eventually a break in the front is established and the wind

funneling through the gap moves the sand landwards, covering extensive areas of

dune and bench."

Causes of dune destabilization are often commented on in other botanical studies in the region. Brown $(1980,29)$ suggested mechanical damage through over-grazing and toofrequent use of fire to provide "green pick". Macphail et al. (1975: 32, 48, 59) stated that wind erosion has been initiated by fire, vehicles, and grazing. Cattle are certainly a new factor, but fire has been used by man to alter the coastal vegetation for millenia (Jones 1969). The questions are: What was the prehistoric fire pattern 1ike? Why did the Aborigines burn the vegetation? What were the patterns of seasonality and frequency? Did these reasons and patterns change with the arrival of Europeans?

\section{ABORIGINAL AND EUROPEAN FIRING PATTERNS}

Fires can be started by lightning (Mount 1964). In this discussion it is assumed that this possibility of natural ignition did not change with the arrival of Europeans.

The first recorded indication that Tasmania was occupied was the sighting of bush fires by Abel Tasman in 1642 (Chapman 1980, 40). Later accounts by the early explorers contain numerous references to sightings of fires or smoke. Some descriptions may refer to either Aboriginal camp fires or bush fires. Only rarely is an unequivocal statement 


\section{Jim Stockton}

like Baudin's description of the D'Entrecasteaux Channel in 1802 given. "... the mountains ... had been constantly on fire since our arrival". A day later he stated "the entire coast to port was ablaze" (Corne11 1974, 331-332).

The reasons for Aboriginal burning of the bush were varied. Fire was used to drive animals from cover in hunting (Plomley 1966, 840, 629). Another aim of burning was to open up dense vegetation (Plomley 1966, 54, 376). This would be done to make travelling easier (Plomley 1966, 287-288) or to keep tracks open (Plomley 1966, 520). This practice was continued by many explorers and prospectors. There is a hint by Robinson that the Aborigines with him burnt dense underwood to get rid of mosquitoes (Plomley 1966, 840). This is an extremely effective mosquito repellent? Bush fires were used by groups of Aborigines to advertise their position (Plomley 1966, 862-863, 288, 513, 740). Aborigines with Robinson on a hill slightly west of Bothwell were prepared to assert that a yellow tinge in the sky far in the west was the result of the natives of the west coast "burning the woods in those parts" (Plomley 1966, 523).

Lighting fires to mark location was also practised by Europeans (Corne11 1974, 441).

While on a lookout a companion showed Robinson the route of a "native track which was visible from the burnt ground" (Plomley 1966, 905). This pattern of firing along access routes has continued up to the present. It is particularly noticeable on modern air photographs of the study area. Many of the modern roads follow prehistoric routes through the study area, perhaps because they developed along routes of easy foot travel through open (i.e. well burnt) country.

As the Aborigines travelled they would light bushfires which could supply them with fire if the firestick they carried went out (Plomley 1966, 560; Corne11 1974, 307). If their fire did go out they had no means of kindling another (Plomley 1966, 740).

The earliest firestick description I am aware of is from 1789 when Mortimer observed several natives "with pieces of lighted wood in their hands" (Mortimer 1975, 18). There were probably preferred types of wood for firesticks. Use of sheoak, Casuarina spp. (probably C. stricta), was mentioned by Robinson (Plomley 1966, 385) but casuarinas are not available in many parts of Tasmania, so other types of wood must also have been used. Robinson also noted the use of tea-tree bark (MeZaleuca spp.) for torches. His use of the term "torches" shows he distinguished them from firesticks. The tea-tree has a layered papery bark which burns very rapidly. It provides a very good light, but is not suitable as a means of transporting fire.

With the arrival of European stock, the practice of firing the country was quickly adopted. It was formally advocated in 1828 by a government surveyor as a means of making land suitable for grazing (Wedge 1861,1 ). Robinson noted his uncertainty of the origins of a fire just below the Western Tiers in 1831 (Plomley 1966, 546). In 1834 he noted: "saw the white man's smoke near Port Sore11" from the top of a hill near the Western Tiers (Plomley 1966, 904; 920 note 136).

\section{SEASONALITY}

To look at the problem of seasonality of Aboriginal burning I have confined my search to Robinson's journals, and within them to his observations of bushfires or recently burnt ground. Some fires recorded may have been started by lightning, but this factor cannot be evaluated.

There are not enough records from the northwestern corner of Tasmania, so I have listed his observations throughout Tasmania. The occurrence of fires by month of year and region is shown in table 2. Even though a total of 19 observations is small, there is a surprising agreement between the pattern for the northwestern coast and the remainder of the island. The overall pattern can be interpreted in several ways. Firstly, burning occurred at all seasons of the year. This is an important point, lightning fires would 
TABLE 2

ROBINSON'S OBSERVATIONS OF BUSH FIRES AND RECENTLY BURNT AREAS.

\begin{tabular}{lllr} 
& $\begin{array}{l}\text { Northern part } \\
\text { of west coast }\end{array}$ & $\begin{array}{l}\text { Other parts } \\
\text { of Tasmania }\end{array}$ & Total \\
$\begin{array}{l}\text { January } \\
\begin{array}{l}\text { February } \\
\text { March }\end{array}\end{array}$ & 849 & 839,840 & 2 \\
$\begin{array}{l}\text { Apri1 } \\
\text { May }\end{array}$ & 858,862 & 842,842 & 3 \\
June & 172,184 & 136 & 3 \\
July & 760 & & \\
$\begin{array}{l}\text { August } \\
\text { September }\end{array}$ & & $188,375,898$ & 4 \\
$\begin{array}{l}\text { October } \\
\text { November }\end{array}$ & 673 & & \\
December & & 249,260 & 3 \\
& & 285 & 1 \\
& & 560 & 1 \\
\hline
\end{tabular}

Page numbers refer to Plomley (1966).

have mostly occurred in summer. Secondly, the sumner season of December through to March accounts for 9 out of 19 observations, suggesting three possible interpretations. One, firing was more common in summer. Two, summer fires burnt for longer. Three, summer fires covered larger areas than winter fires and so were more visible. Also, Robinson preferred to carry out field operations in summer, which leads to an imbalance in the seasonality of his records. One longtime resident of the west coast, Mr R. Wainwright, has deseribed the burning patterns followed in the 1920's and 1930's on woolnorth, the Van Diemen's Land Company property at the northern end of the study area (pers. comm.). Management here was typical of the northwestern region from the 1830 's to about 1950 . All the country was kept well burnt. The higher plains country was fired in September as soon as it was dry enough. The lower country and swamps were fired in summer, but while the peat was still too wet to burn. If the grazing land was not burnt regularly it would change from grassland to scrub. The transition of grazing land to scrub has since occurred at welcome Marsh and several other areas as regular firing was not continued after about 1950. Mr Wainwright also commented on two important prehistoric food species which were snared for skins and meat by settlers, the brush possum, Trichosurus vulpecula and the red-bellied pademelon, Thyzogale bilzardierii. In his days as a snarer, they would burn eucalypt forest to encourage regrowth on which the possums feed. Unburnt forest had very few possums. Similarly, snarers got few wallabies in unburnt areas, and these animals were usually in poor condition. So burning improved the living conditions of both possums and wallabies.

Fire ecology in Tasmania is a young field study and still an area of sometimes emotional contention. To date attention has focussed on forest succession (Jackson 1968; Mount 1964, 1979), with only passing reference to coastal heaths (Jackson 1965, 30). Kirkpatrick's review of heath communities (1977a) deals only with Hunter Island in the study area. Judging from the evidence reviewed, there were no detectable major changes in fire frequency in the transition from Aboriginal to European occupation of the wcst coast (Kirkpatrick 1977b). Although the ultimate aims of the two cultures werc irreconcilable, the means they used to manage the vegetation were similar. The arrival of cattle on the landscape is the factor which coincides with the destabilization of the grassland community on sandhills. Historical evidence in the study area suggests that the effect of cattle grazing on the sandsheet landforms does not necessarily lead to the development of sand blows, but in the majority of locations this has occurred. 
Today, there is a new vegetation type which dominates a large proportion of the coast - the marram grass community. Marram grass, Ammophizza arenaria, is a species which colonizes and binds free sand much more rapidly than native grasses. It was introduced to Australia by Baron von Mueller, and was being used in northwestern Tasmania at Stanley to stabilize mobile dunes by 1895 (Ashworth and le Soeuf 1895,136 ). Being a specialized colonizing plant, it cannot compete with established vegetation, but the destabilization of the coastal sandsheets and deliberate planting programs account for its widespread distribution. In the vegetation of the 1820's and $1830^{\prime} \mathrm{s}$ it would probably not have been able to gain a place.

\section{CONCLUSIONS}

of the vegetation comunities found on the west coast during the exploration pexiod of 1820 to 1840 the one which has persisted most successfully is the heath community. The small swamps of the coastal fringe have also remained. The bulk of the woodland community on the basaltic soil areas has been cleared and sown to pasture, and the woodland community is now seen only as remnants. The grassland community on stable sand dune landforms has changed in two ways. Firstly, the remnant stable dunes in the area now contain many introduced species. Secondly, a large proportion of this landform has destabilized into mobile sandsheets. On these unstable sandsheets a new community has developed, the marram tussock grass community.

The date of the initial development of the sand blows is uncertain, but none of the explorers record observations of unvegetated sand dunes, although it seems probable that some existed.

By 1894 there were sandblows at Stanley on the north coast (Ashworth and le Soeuf 1895, 136). By 1934 sand blows at Sandy Cape had extended $3.2 \mathrm{~km}$ inland (Circular Head Chronicle $31.1 .34,1)$. The probable date of the start of the process is between 1848 and 1890 .

From evidence reviewed on Aboriginal and European use of fire, there is no definite indication of a change in frequency or seasonality pattern. The introduction of European stock is the factor which coincided with the start of widespread sand dune mobilization.

\section{ACKNOWLEDGMENTS}

The fieldwork for this paper was carried out while I was a student in the Department of Prehistory, Australian National University. Discussion on the topic with Colin Bastick (Dept of Agriculture), David Steane (Lands Department) and Bob Mesibov (Forestry Commission) is gratefully acknowledged, but I alone am responsible for the opinions expressed. Early drafts of the paper were read by Laila Haglund, Mark Noble, Geoff Hope and Robin Clarke. Grass identifications were made by D.I. Morris of the Dept of Agriculture.

\section{REFERENCES}

Ashworth, H.P.C. and Le Souef, D., 1895: Albatross Island and the Hunter Group. Vic. Nat., 11: 134-144

Brown, M.J., 1980: The vegetation of the Mt Cameron West aboriginal site. Pap. Proc. R. Soc. Tasm., 114: 21-34

Chapman, P., 1980: Tasman and a Dutch discovery. Aust. Nat. Hist., 20(2): 39-42.

CIRCULAR HEAD CHRONICLE, 31 st January 1934.

Cornel1, C., 1974: THE JOURNAL OF POST CAPTAIN NICHOLAS BAUDIN, COMMANDER-IN-CHIEF OF THE CORVETTES GEOGRAPHE AND NATURALISTE. Libraries Board of South Australia: Adelaide.

Davies, J.L., 1965: Landforms. In Davies, J.I. (Ed.): ATLAS OF TASMANIA. Lands and Surveys Department, Hobart: 19-26.

Fossey, J., 1861: Report of Mr Joseph Fossey, Paritamentary Papers, 16: 9-10. 
Galloway, R.W., Storey, R., Cooper, R. and Yapp, G.A., 1980: COASTAL LANDS OF AUSTRALIA. $80 / 24 ;$ C.S.I.R.O., Canberra.

Goldie, A., 1861: Report of Mr Alexander Goldie, of his journey from George Town to Cape Grim and the western coast, dated 28th November, 1826, Parizamentary Papers, 16: 5-8. Hardwicke, Capt., 1861: Remarks upon the north coast of Van Diemen's Land from Port Dalrymple to the north-west extremity; and from thence four Leagues to southward of West Point on the west Coast. Parlimentary Papers, 16: 1-2.

Hellyer, H., 1861: Report of Mr Henry Hellyer, dated Circular Head, 13 March, 1827. Parizamentary Papers, 21: 1-7.

Hooker, J.D., 1860: FLORA OF TASMANIA, Lovell Reeve: London.

Jackson, W.D., 1965: Vegetation. In Davies, J.L. (Ed.) : ATIAS OF TASMANIA. Lands Department, Hobart: $30-35$. 1968: Eire, air, water and earth - an elemental ecology of Tasmania. Proc. Ecol. Soc. Aust., 3: 9-16.

Jones, R., 1969: Fire-stick farming. Aust. Nat. Hist., 16: 224-228.

Kirkpatrick, J.B., 1977a: THE DISAPPEARING HEATH. The Tasmanian Conservation Trust: Hobart.

, 1977b: Native vegetation of the West Coast region of Tasmania. In Banks, M.R. and Kirkpatrick, J.B. (Eds): I.ANDSCAPE AND MAN; THE INTERACTION BETWEEN MAN AND ENVIRONMENT IN WESTERN TASMANIA. ROYal Society of Tasmania, Hobart: 55-80. Legge, R.W., 1929: Tasmanian Aboriginal Middens of the West Coast. A.A.A.S., 19: 323-328. Lorymer, C.F., 1861: Exploring report, by C.P. Lorymer, Surveyor Ec. to the Van Diemen's Land Company. Parliamentary Papers, 16: 12-13.

Mackaness, G., 1976: CAPTAIN WILLIAM BLIGH'S DISCOVERIES AND OBSERVATIONS IN VAN DIEMEN'S IAND. Review Publications: Dubbo.

Macphail, M., Shepherd, R.R. and Brown, M., 1975: NORFOLK AREA ENVIRONMENT STUDY. Report. to the Australian Department of the Environment and Conservation.

Mortimer, G., 1975: OBSERVATIONS AND REMARKS MADE DURING A VOYAGE TO THE ISLANDS OF TENERIFEE, AMSTERDAM, MARIA'S ISLANDS NEAR VAN DIEMEN'S LAND; OTAHEITE, SANDWHICH ISLANDS; OWHYHEE, THE FOX ISLANDS ON THE NORTH WEST COAST OF AMERICA, TINIAN, AND EROM THENCE TO CANTON IN THE BRIG MERCURY. London. Reprinted by N. Israel/ Keizersgracht, Amsterdam.

Mount, A.B., 1964: The interdependence of the eucalypts and forest fires in southern Australia. Aust. For., 28(3): 166-172. $180-186$ 1979: Natural regeneration processes in Tasmanian forests. Search, 10(5):

Plomley, N.J.B., (Ed.), 1966: FRIENDLY MISSION. THE TASMANIAN JOURNALS AND PAPERS OF GEORGE AUGUSTUS ROBINSON 1829-1834. Tasmanian Historical Research Association, Hobart.

Stockton, J., 1979: Cultural resources information for Cape Grim, northwest Tasmania. Aust. Heritage Comn., Canberra, unpubl. rept.

Wedge, J.H., 1861: Official report of journeys made by J.H. Wedge, Esq., Assistant Surveyor, in the north-west portion of Van Diemen's Land, in the early part of the year 1828. Parziamentary Papers, 21: 1-6.

- 1962: THE DIARIES OF JOHN HELDER WEDGE 1824-1835. Edited by The Hon. Mr Justice Crawford, G., Ellis, W.F. and Stancombe, G.H. Royal Society of Tasmania, Hobart.

V.D.L./343/5 North West Coast Map of the North west quarter of Van Diemen's Land to accompany the Third Annual Report of the V.D.I. Co. 1 inch to 9 miles. Printed C. 1828 (for report see V.D.L./203). 
AfPENDIX 1

HISTORIC AND MODERN VEGETATION PATTERNS.

1. Big Duck Bay to Perigo Point, Hunter Island. Past veg: low grassy sandhills with clumps of honeysuckle trees - good feed for sheep (1832)

Present veg: pasture grasses with scattere

Eucatyptus sp. and Banksia Marginata

$$
\text { trees }
$$

obs. \& ref: Robinson (Plomley 1966,657 )

2. Trefoil Island

Past veg: beautiful pasture (1830)

Present veg: Foa tussock grassland

Obs, \& ref: Robinson (Flomley 1966,175).

3. Woolnorth Foint.

Past veg: a rich grass pasture on the coast,

with heath inland (c. 1824)

Present veg: introduced pasture species

Obs. \& ref: Hardwicke $(1861,2)$.

4. Woolnorth point to Studland Bay.

Past veg: good sheep land (c. 1828)

Present veg: introduced pasture specie obs. \& ref: VDL $/ 343 / 5$.

5. Cape Grim to Arthur River.

Past veg: nearly all the country is qrassy sandhills, and excellent sheep walks (1832)

Present veg: too varied to describe, see references 7 to 32 .

Obs. \& ref: Robinson (Plomley 1966,616).

6. Cape Grim to Mount Cameron west - coastal strip. Fast veg: abundance of feed for sheep (1828) Present veg: as for 5

obs, \& ref: Wedge $(1861,3)$
7. Cape Grim and vicinity.

Past veg: good sheep land with the exception of low plain which is suitable for cattle (1826)

Present veg: cultivated areas of pasture grasses and areas of closed shrubs of helaleuca emicifolia. Poa tussock grassland on hillslopes

obs. a ref: Goldie $(1861,6)$.

8. Cape Grim.

Fast veg: luxuriant grass, fine country for sheep (1828)

Present veg: as for 7

Obs. \& ref: Wedge $(1861,3)$.

9. Cape Grim (?)

Past veg: grassy hills (1830)

Fresent veq: as for 7

obs. \& ref: Robinson (Elomley 1966,175).

10. Flat Topped Bluff.

Past veg: grass and stunted tea-tree (1830)

Present veg: as for 7

obs. \& ref: Robinson (Plomley 1966,174 ).

1. SW of Welcome Inlet.

Past veg: extensive forest of tea-tree light and blackwood (1834)

Present veg: low forest of very dense low trees dominated by $M$. emicifolia with

scattered Acacia melanoxilon

Obs. \& ref: Robinson (Plomley 1966,865).

12. W of WeIcome Inlet.

Past veg: tea-tree and heathy swamp land (1832)

Present veg: mainly an open heath and sedgeland

comprising $M$ squarrosa, $M$. ericifolia

and Leptospermim scoparium

Obs. \& ref: Robinson (Plomley 1966,656 ). 
13. Studland Bay.

Past veg: good sheep land (1826)

Present veg: bare mobile sand blows

obs. \& ref: Goldie $(1861,6)$.

14. Inland from Studland Bay.

Past veg: good sheep pasture (1832)

obs. \& ref: Robinson (Plomley 1966,656 ).

15. Mount Cameron west.

Past veg: covered with grass and large gum an peppermint trees, an open forest of

Present veg: tussock grassland with areas of very dense $M$. ericifolia scrub. On the southern slopes is Eucalyptus woodland with a heath understorey

Obs. \& ref: Robinson (Plomley 1966, 174).

16. View from Mount Cameron West.

Past veg: broad extensive plains covered with grass and small grassy hills, and small belts of open forest interspersed throughout (1830)

Present veg: sand blows and restabilized areas with marram grass.

Obs, \& ref: Robinson (Plomley 1966,174).

17. Mount Cameron West vicinity (?N side) Past veg: heath and swamp (1826) veg: as for 16

obs. \& ref: Goldie $(1861,6)$.

18. Mount Cameron West

Past veg: very good feed (1826)

Present veg: pasture grasses on flat areas, and tussock grassland with areas of very dense $M$. exicifolia scrub on slopes. Obs. \& ref: Goldie $(1861,6)$.

19. Mount Cameron west and the adjacent coastal strip. Past veg: luxuriant pasturage (1828) Present veg: as for 18 Obs. \& ref: Wedge $(1961,3)$.
20. N, E and $S$ of Mount Cameron west.

resent veg: restabilized sand blows with marram grass along the coastal fringe, with heath or Eucalyptus woodland with a heath understorey in inland areas

obs. \& ref: VDL/343/5.

21. Mount Cameron West to West Point.

Past veg: narrow coastal strip of good land with

Present veg: the coastal strip is now a complex pattern of marram grass restabilized dunes. pasture covered relict dunes, and coastal forest areas are now cleared and sow tho forest areas are now cleared and sown to pasture.

Obs. \& ref: Wedge $(1861,3)$

22. Port Hills.

Past veg: same as Mount Cameron West - very good feed (1826)

Present veg: introduced pasture species

obs. \& ref: Goldie $(1861,6)$.

23. West Point c. $3 \mathrm{~km}$ inland.

Past veg: wet heathy plains and tea tree knee deep in water (1826)

Present veg: heath dominated by $L$. scoparium-M. squarrosa

association and swamps with $M$. ericifolia

obs. \& ref: Goldie $(1861,6)$.

24. West Point.

Past veg: small quantities of land adapted for sheep 1828

Present veg: grassland on the coastal fringe, with heath inland

obs. \& ref: Wedge $(1861,3)$

25. West Point.

Past veg: an extensive heathy plain (1832)

Present veg: as for 24

Obs. \& ref: Robinson (Plomley 1966,653). 
26. West Point (? S of the point).

Past veg: miles of grassy sanahills ... an excellent sheep walk (1832)

Present veg: sand blows restabilized with marram grass

obs. \& ref: Robinson (Plomley 1966,616).

27. West Point to Bluff Hill Point.

Past veg: grassy hills covered with honeysuckle trees (1830)

Present veg: at West Point and Bluff Hill

Point there are remnant stable dune

landforms with vegetation similar to

the reference. Elsewhere the coastal strip is sand blows restabilized with strip is

Obs. \& ref: Robinson (Plomley 1966,172).

28. Coastal strip $1.5 \mathrm{~km}$ wide from $8 \mathrm{~km} \mathrm{~S}$ of west Point to the Arthur River.

Past veg: good sheep land (c. 1828)

Present veg: marram grass on restabilized dunes with coastal heath inland

Obs. \& ref: VDL/343/5.

29. C. $8 \mathrm{~km} \mathrm{~S}$ of West Point.

Past veg: a rich grass pasture on the coast with heath inland (c. 1824)

Present veg: as for 28 .

Obs. \& ref: Hardwicke $(1861,2)$

30. Australia Point to Temma. Past veg: grassy hills with dwarf gum and

Present veg: recently mobile sand blows near the coast have been stabilized with marram grass. Inland dunes which have remained intact are covered with Lomandra longifolia tussock grassland, introduced pasture grasses and clumps of Leptospermum laevigatum and A. sophorae.
31. Arthur River mouth.

Past veg: the banks are high and hilly and covered with grass (1830)

Present veg: as for 30

obs. \& ref: Robinson (Plomley 1966,171-2).

32. Arthur River, $1-2 \mathrm{~km}$ inland. Past veg: heath with clumps of scattered gum trees (1834) Present veg: as described in reference

obs. \& ref: Robinson (Plomley 1966,849).

33. Coastal strip $1.5 \mathrm{~km}$ wide from $3 \mathrm{~km} \mathrm{~S}$ of the Arthur River to $11 \mathrm{~km} \mathrm{~S}$ of the Pieman River.

Past veg: good sheep land (c, 1828)

Present veg: this strip is mostly unvegetated mobile sand blows and marram restabilized dunes. flows and marram restabilized dunes. Inland ger the sandsheets is quartzite bedrock

Obs. \& ref: VDL $/ 343 / 5$.

34. Sundown Point to Sandy Cape.

Past veg: honeysuckle and other trees and copses are interspersed over the country with clear heathy plains and hills ... good sheep walks (1833)

Present veg: remnant dune areas have pasture grasses with scattered trees and shrubs, but most dune areas have become unstable sand blows. Some of the sand blows have been restabilized by marram grass. Non-dune landforms on the quartzite bedrock have coastal heath.

Obs. \& ref: Robinson (Plomley 1966,790).

35. $2 \mathrm{~km} \mathrm{~N}$ of Temma to Thornton River.

Past veg: the whole extent of the country is clear of wood, with undulating grassy patches heathy hills, and has the appearance of a park (1830)

Present veg: as for 34

obs. \& ref: Robinson (Plomley 1966,170). 
36. Pedder River, c. $2 \mathrm{~km}$ inland.

Past veg: good grassy meadows, each one enclosed with honeysuckle and teatree (1830)

Present veg: areas of tussock grass and other herbs, with clumps of shrubs, mostl Leptospermum Zaevigatum and Acacia sophorae. Melalenca exicifolia dominates the damp area.

obs. \& ref: Robinson (Flomley 1966,168 ).

37. Sandy Cape.

Past veg: plains and small grassy hills (I830)

Present veg: mobile unvegetated sand blows and

marram grass restabilized dunes.

16 km sof Sandy Cape to (3) Sandy cape.

Past veg: a fine belt of grassy hills comnenca fine belt of grassy hills com
ing $16 \mathrm{~km} S$ of sandy Cape, well adapted for a sheep walk (1833)

Present veg: huge unvegetated mobile sand dunes are the dominant landform. Behin some areas of rocky headland are remnants of stable dune landforms vegetated by grassland and coasta heath.

Obs. \& ref: Robinson (Plomley 1966,789$)$.

39. N of Lagoon River Past veg: resembles in appearance of park with extensive grassy hills with honeyer $(1830)$

Present veg: mobile unvegetated sand blows and stable dune areas with vegetation of grassland with scattered shrubs of Banksia margina

obs. \& ref: Robinson (Plomley 1966, 166).
40. $S$ of Lagoon River.

past veg: extensive plains with grassy hills (1830)

Present veg: mobile sand blows

Obs. \& ref: Robinson (Plomley 1966,166).

41. W foothills of North Heemskirk Spur, Mount Heemskirk and Cumberland Hill.

Past veg: the land covered with heath and fine

shrubs for several miles... the land

covered with heath and a few shrubs (1830) moor and heathy land (1833)

Present veg: mixed heath and sedgeland communities, of which the principal species are Leptospermum nitidum, Epacris Ianuginosa, Banksia marginata and Leptospermum scoparizom.

obs. \& ref: Robinson (Plomley 1966, 760).

Ocean Beach.

Past veg: a sandy beach $800 \mathrm{~m}$ in width in the rear of which are sandy hills (1830)

Present veg: about half this strip is mobile sand blows. The remainder is stable sand dune landforms with an open scrub. Principal species are A. mucronata, A. sophorae and Leptospermum scoparium.

Obs. \& ref: Robinson (Plomley 1966,160). 